\title{
Chemical composition of corn and sorghum grains cultivated in Oxisol with different application methods and doses of zinc
}

\author{
Aline P. Puga ${ }^{1}$, Renato de Mello Prado 2 , Ben-Hur Mattiuz², Diego Wyllyam \\ do Vale 3 , and Ivana M. Fonseca ${ }^{4}$ \\ ${ }^{1}$ Instituto Agronômico de Campinas (IAC), Avenida Barão de Itapura, 1481- Campinas (SP), Brazil. \\ ${ }^{2}$ Faculdade de Ciências Agrárias e Veterinárias (FCAV), Universidade Paulista Júlio de Mesquita Filho \\ (UNESP). Via de acesso Prof. Paulo Donato Castellane, s/n. - Jaboticabal (SP), Brazil. \\ ${ }^{3}$ Escola Superior de Agricultura "Luiz de Queiroz" (ESALQ), Universidade de São Paulo (USP). Avenida \\ Pádua Dias, 11 - Piracicaba (SP), Brazil. \\ ${ }^{4}$ Embrapa Cocais, Avenida São Luís Rei de França, 4 Qd 11 - São Luís (MA), Brazil.
}

\begin{abstract}
A.P. Puga, R.M. Prado, B. Mattiuz, D.W. Vale, and I.M. Fonseca. 2013. Chemical composition of corn and sorghum grains cultivated in Oxisol according to different application methods and doses of zinc. Cien. Inv. Agr. 40(1):97-108. In general, tropical soils present low concentrations of zinc ( $\mathrm{Zn})$, and the deficiency of $\mathrm{Zn}$ is recognized as a world nutritional problem for cereal production and human beings. Therefore, the main goal of this study was to assess the effects of different methods of $\mathrm{Zn}$ application on the quality of corn and sorghum grains grown in Oxisol. Two experiments were set up in the experimental area of UNESP (campus of Jaboticabal, Brazil). The following nine treatments were applied: three doses of $\mathrm{Zn}$ by banded application (seed furrows), three doses of $\mathrm{Zn}$ by incorporation into soil (0-20 cm depth), foliar application, seed application, and control (no $\mathrm{Zn}$ applied). The treatments were arranged in randomized blocks with four replicates. The contents of $\mathrm{Zn}$, carbohydrates and proteins were determined for corn and sorghum grains. Regardless of the method, $\mathrm{Zn}$ application promoted higher contents of this micronutrient in corn and sorghum grains. The banded application method of $\mathrm{Zn}$ in soil promoted greater contents of total carbohydrates, starch and protein in both cultures. The incorporation of $\mathrm{Zn}$ into the soil method provided higher contents of soluble carbohydrates in both corn and sorghum grains.
\end{abstract}

Key words: Carbohydrate, protein, Sorghum bicolor, Zea mays L., Zn.

\section{Introduction}

Cereals are grasses mostly cultivated for their edible grains, and they represent important source of minerals and proteins in the developing world. Grains are used as basic food stock in most countries (Cakmak, 2008).

Received June 4, 2012. Accepted December 18, 2012. Corresponding author: linepuga@yahoo.com.br
In developing countries, the diet is often based on cereal consumption, which has low $\mathrm{Zn}(\mathrm{Zn})$ content and bioavailability (Cakmak et al., 2010). The most frequent deficiencies in humans are those of iron, $\mathrm{Zn}$, iodine and vitamin $\mathrm{A}$, and these deficiencies occur especially among women and children in developing countries (WHO, 2002). Zn deficiency in humans is common, and it is estimated to affect $25 \%$ of the world population (Maret and Sandstead, 
2006), especially in several regions with soils deficient in $\mathrm{Zn}$, including India, Pakistan, China, Iran and Turkey (Cakmak et al., 1999, Hotz and Brown, 2004). The lack of this micronutrient in human beings is responsible for severe health complications, including problems in physical growth; damage to the immune system; damage to learning ability; and increased risk of infections, DNA damage and cancer development (Gibson, 2006; Hotz and Brown, 2004; Prasad, 2007).

It is possible that low quality cereal grains occur because the main goal of plant breeding programs has been to increase yield during the last decades (Peleg et al., 2008). However, the nutritional composition is equally important and has been largely neglected in such programs, especially concerning micronutrient contents (Cakmak, 2002). Thus, future studies assessing more efficient $\mathrm{Zn}$ application methods to promote $\mathrm{Zn}$ uptake in plants and to maximize the accumulation of this micronutrient in grains must be developed (Camak, 2008).

In soils with slight $\mathrm{Zn}$ deficiency, the yields and quality can be affected without any evident symptoms (Alloway, 2009), which can result in food production with comprised nutritional value. Therefore, the enrichment of such cereals with $\mathrm{Zn}$ is an important global challenge and of great priority in research (Cakmak et al., 2010).

Cereals often present low contents of proteins and micronutrients, including iron and Zn (Newell, 2008). According to Peck et al. (2008), no studies have been conducted to evaluate the effect of $\mathrm{Zn}$ on the quality of grains or to assess if the increase of available $\mathrm{Zn}$ can raise protein concentration in grains (Hemantaranjan and Garg, 1988) because Zn deficiency results in low protein content in plants (Moinuddin and Imas, 2010). Such decrement is due to decreased RNA as well as the deformation and reduction of ribosomes (Brown et al., 1993).

In addition, a few field studies on wheat have suggested that the application of fertilizer containing
$\mathrm{Zn}$ increases the productivity and concentration of $\mathrm{Zn}$ in grains by approximately 3.5-fold by soil and foliar application methods in calcareous soils (Yilmaz et al., 1997).

Studies on Zn with different crops have also been conducted in other locations as follows: beans in Germany (Cakmak et al., 1989), potatoes in Iran (Mousavi et al., 2007) and wheat in Turkey (Ozturka et al., 2006). Nevertheless, there is a lack of studies concerning this micronutrient in Brazil, especially in field conditions. Therefore, agronomic techniques suitable to elevate $\mathrm{Zn}$, protein and carbohydrate contents both quantitatively and qualitatively in grains are of great importance and should be extended to other cultures and in different edaphoclimatic conditions.

Thus, the main goal of this study was to assess the effects of different $\mathrm{Zn}$ application methods and doses on grain quality for corn and sorghum grown in Oxisols.

\section{Materials and methods}

The experiment was conducted at FCAV/UNESP ( $21^{\circ} 15^{\prime} 22^{\prime \prime} \mathrm{S}$ and $48^{\circ} 18^{\prime} 58^{\prime \prime} \mathrm{W}$; altitude of 575 $\mathrm{m})$ in Oxisol with a clay texture according to EMBRAPA (2006). Based on the international classification of Köppen, the climate of the region is Cwa. The soil chemical analysis (0 to $20 \mathrm{~cm}$ soil layer) was performed according the methods described by Raij et al. (2001) and had the following properties: $\mathrm{pH}$ in $\mathrm{CaCl}_{2}=5.5$; organic matter $(\mathrm{OM})=1.6 \%$; $($ resin $)=31 \mathrm{mg}$ $\mathrm{kg} ; \mathrm{K}=0.11 \mathrm{cmol}_{\mathrm{c}} \mathrm{kg}^{-1} ; \mathrm{Ca}=2.5 \mathrm{cmol}_{\mathrm{c}} \mathrm{kg}^{-1} ; \mathrm{Mg}$ $=1.2 \mathrm{cmol}_{\mathrm{c}} \mathrm{kg}^{-1} ; \mathrm{H}+\mathrm{Al}=2.2 \mathrm{cmol}_{\mathrm{c}} \mathrm{kg}^{-1} ; \mathrm{sum}$ of bases (SB) $=3.8 \mathrm{cmol}_{\mathrm{c}} \mathrm{kg}^{-1} ; \mathrm{CEC}=6.0 \mathrm{cmol}_{\mathrm{c}}$ $\mathrm{dm}^{-3} ; \mathrm{V} \%=63 ; \mathrm{S}=1.0 \mathrm{mg} \mathrm{kg}^{-1} ; \mathrm{B}=0.30 \mathrm{mg} \mathrm{kg}^{-1}$; $\mathrm{Cu}=1.0 \mathrm{mg} \mathrm{kg}^{-1} ; \mathrm{Fe}=13.0 \mathrm{mg} \mathrm{kg}^{-1} ; \mathrm{Mn}=16.1$ $\mathrm{mg} \mathrm{kg}^{-1}$; and $\mathrm{Zn}=0.5 \mathrm{mg} \mathrm{kg}^{-1}$. According to the interpretation of Raij et al. (1997), the content of $\mathrm{Zn}$ in this area is considered low, therefore, a deficient condition. 
The plots were composed of four lines that were $5 \mathrm{~m}$ in length. The two central lines were used for sowing, and the other lines were used as borders with a spacing between lines of $0.9 \mathrm{~m}$ for corn and $0.45 \mathrm{~m}$ for sorghum. A simple hybrid of corn (Impacto) and simple hybrid of sorghum (Dow822) were used. Sowing was carried out in December 2008, and the medium precipitation during the experimental period from sowing to harvest was $996 \mathrm{~mm}$. The average temperature of the period was $23.8^{\circ} \mathrm{C}$. No irrigation system was used.

At the time of sowing, basic fertilization was applied uniformly in all treatments with the following composition: $30 \mathrm{~kg} \mathrm{ha}^{-1} \mathrm{~N}, 50 \mathrm{~kg} \mathrm{ha}^{-1}$ $\mathrm{P}_{2} \mathrm{O}_{5}$ and $50 \mathrm{~kg} \mathrm{ha}^{-1}$ of $\mathrm{K}_{2} \mathrm{O}$ in the form of urea and NPK fertilizer (02-20-20).

The following nine treatments were applied: three doses of $\mathrm{Zn}\left(2,4\right.$ and $8 \mathrm{~kg}$ of $\left.\mathrm{Zn} \mathrm{ha} \mathrm{n}^{-1}\right)$ by banded application (seed furrows), three doses of $\mathrm{Zn}(6$, 12 and $24 \mathrm{~kg}$ of $\left.\mathrm{Zn} \mathrm{ha}{ }^{-1}\right)$ incorporated into soil (0-20 cm depth), foliar application (0.4 kg of Zn $\mathrm{ha}^{-1}$ ), seed application (40 $\mathrm{g}$ of $\mathrm{Zn} \mathrm{kg}^{-1}$ of seeds), and control (no $\mathrm{Zn}$ application). The treatments based on soil and foliar application received $\mathrm{Zn}$ in the form of $\mathrm{Zn}$ sulfate $(22.7 \% \mathrm{Zn}$ and $11 \% \mathrm{~S})$, and treatments applied to seeds used $\mathrm{Zn}$ oxide (79\% $\mathrm{Zn})$. The first foliar application was performed 15 days after emergence, and the second application was performed 30 days after emergence. Before the seed application, a sugar solution was applied to the seeds to ensure higher adhesion of fertilizer. The experimental design included randomized blocks with four replicates.

Harvest was performed when grains of both cultures had an approximate humidity of $13 \%$, which was approximately 150 days after emergence of plants. The grains were then oven-dried with forced air circulation $\left(65-70{ }^{\circ} \mathrm{C}\right)$ and pulverized. The material was digested by the nitric/perchloric acid procedure according to Bataglia et al. (1983), and $\mathrm{Zn}$ content was determined by atomic absorption spectrometry.
The carbohydrate content in grains was determined according the method described by Nelson (1944) and adapted by Somogyi (1952). To analyze the starch content, the samples were previously subjected to acid hydrolysis and determined by the previously cited method.

Samples were analyzed for crude protein (CP) by the Dumas combustion method using a nitrogen AutoAnalyzer (LECO ${ }^{\circledR}$, model FP-528) (Wiles et al., 1998).

The data from the studied variables were subjected to variance analysis by the F-test and using the degrees of freedom from treatments in orthogonal contrasts. Moreover, a polynomial regression was performed for doses pertaining to the $\mathrm{Zn}$ application methods via soil. More experimental details are presented in Puga (2011).

\section{Results and discussion}

Treatment effects on nutrient contents in grains

With regard to the $\mathrm{Zn}$ content in grains from the corn culture, it was noted that the $\mathrm{Zn}$ application promoted higher $\mathrm{Zn}$ content (24 to $28 \mathrm{mg} \mathrm{kg}^{-1}$ ) compared to the control (19 $\left.\mathrm{mg} \mathrm{kg}^{-1}\right)$ (Table 1). When studying the correlation of Zn deficiency in corn, Galrão (1994) observed that the contents of this micronutrient in grains varies little among treatments ( $\mathrm{Zn}$ application methods), which was similar to the present findings. Ferreira et al. (2001) reported that the $\mathrm{Zn}$ content in grains increases by $7 \%$ due to the application in seed furrows, but the increase reached $32 \%$ in the present study. Similarly, when studying doses of $\mathrm{Zn}$ applied in soil for corn culture, Kanwal et al. (2010) noted significant increments in the content of this micronutrient in corn grains (21.8 to $\left.30.7 \mathrm{mg} \mathrm{kg}^{-1}\right)$.

According to Welch (2002), increasing the $\mathrm{Zn}$ application in soil significantly increases its concentration in edible parts of plants from food cultures. Relatively greater $\mathrm{Zn}$ contents in corn 


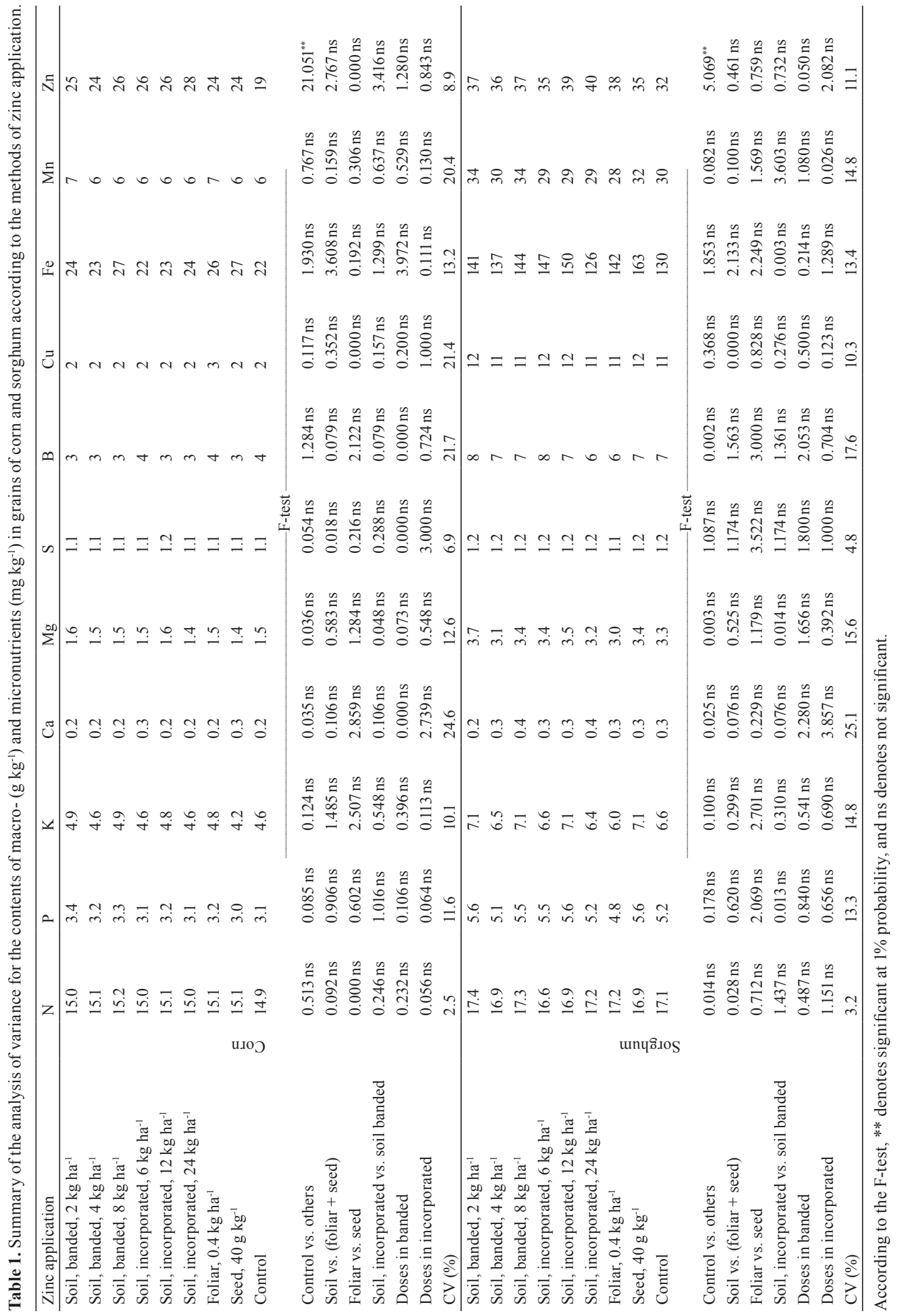


grains are vital to human nutrition and are thus essential to the biofortification of basic food crops (Graham et al., 1992). However, accumulation of Zn in grains or seeds is a complex and intricate process that comprises a series of steps from its translocation from roots to shoot and finally to the phloem unloading for grain development (Welch, 1986).

For the nutrient content in sorghum grains, there were no significant differences for the macro- and micronutrients assessed, except for $\mathrm{Zn}$ (Table 1), in all tested treatments. The application of $\mathrm{Zn}$ resulted in higher $\mathrm{Zn}$ content ( 35 to $40 \mathrm{mg} \mathrm{kg}^{-1}$ ) in grains compared to the control $\left(32 \mathrm{mg} \mathrm{kg}^{-1}\right)$.

Similar to the corn culture, there was only differences in the first comparison group (Table 1) in which the application of $\mathrm{Zn}$ resulted in higher $\mathrm{Zn}$ content compared to the control. When studying foliar application of $\mathrm{Zn}$ in wheat, Ozturka et al. (2006) found that the greater accumulation of $\mathrm{Zn}$ during grain development occurs in the initial stage of grain formation (milk grain stage) suggesting that the foliar application of $\mathrm{Zn}$ during the final stage of wheat growth can be an effective way of increasing the $\mathrm{Zn}$ concentration in grains.

\section{Effects of treatments on carbohydrate contents in grains}

For the corn culture, in the first comparison group tested (control vs. other treatments) (Table 2 ), there were no differences in all the variables analyzed (soluble carbohydrates, starch and total carbohydrates).

Moreover, there were no significant differences between the soil application and plant application treatments (Table 2) as well as between the soil application and seed application. However, Mousavi et al. (2007) studied foliar application of $\mathrm{Zn}$ sulfate in potato crops and demonstrated that higher doses of this element increases starch content in potatoes.
With regard to the Zn applications in soil, the banded application provided higher contents of soluble carbohydrates, starch and total carbohydrates. According to Dechen and Nachtigall (2006), plants have low starch contents when deficient for $\mathrm{Zn}$.

When $\mathrm{Zn}$ was applied to the soil, differences were observed among doses. The banded application of $\mathrm{Zn}$ promoted a decrease with linear adjustment in soluble carbohydrate content (Figure 1a) and a quadratic adjustment in the starch content (Figure 1b) (maximum point of $3.7 \mathrm{~kg} \mathrm{ha}^{-1}$ ) and total carbohydrate content (Figure 1c) (maximum point of $3.6 \mathrm{~kg} \mathrm{ha}^{-1}$ ) in corn grains.
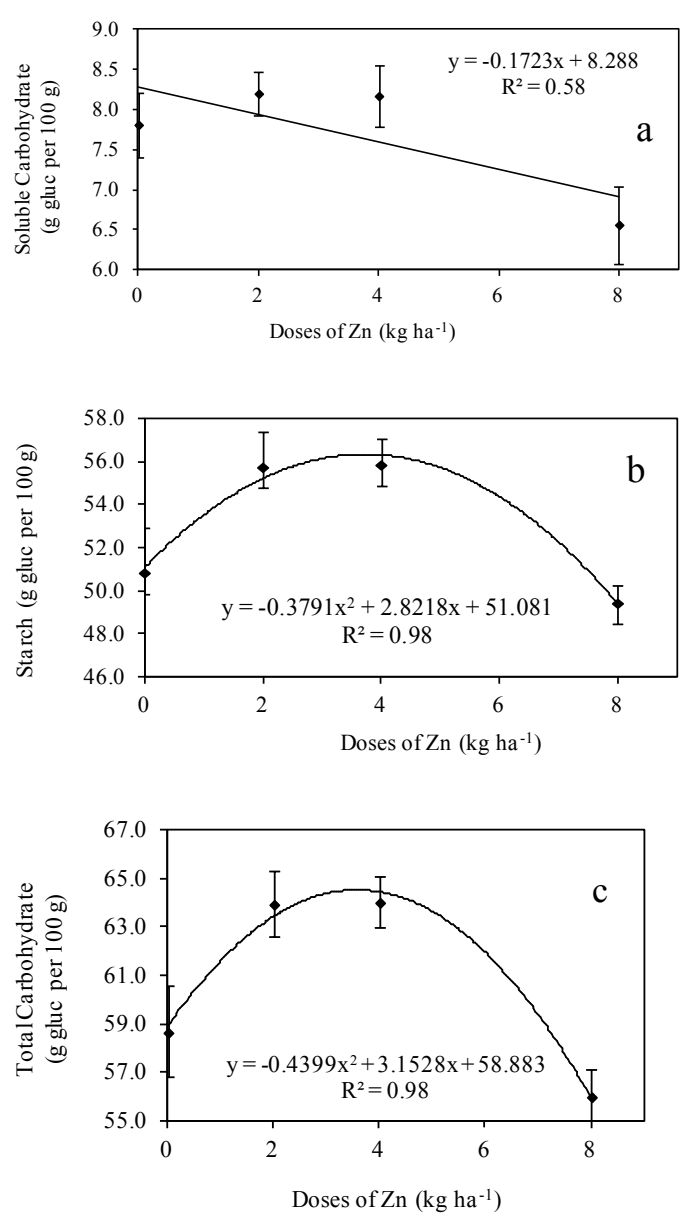

Figure 1. Contents of soluble carbohydrates (a), starch (b) and total carbohydrates (c) in corn grains according to the banded application of $\mathrm{Zn}$ in soil. 
Table 2. Summary of the variance analysis regarding starch, soluble and total carbohydrate contents in corn and sorghum crops according to different $\mathrm{Zn}$ application methods.

\begin{tabular}{|c|c|c|c|}
\hline Zinc application & Soluble Carbohydrates & Starch & Total Carbohydrates \\
\hline Corn & \multicolumn{3}{|c|}{ g glucose per100 g } \\
\hline Soil, banded, $2 \mathrm{~kg} \mathrm{ha}^{-1}$ & 8.20 & 55.77 & 63.97 \\
\hline Soil, banded, $4 \mathrm{~kg} \mathrm{ha}^{-1}$ & 8.17 & 55.88 & 64.05 \\
\hline Soil, banded, $8 \mathrm{~kg} \mathrm{ha}^{-1}$ & 6.56 & 49.46 & 56.02 \\
\hline Soil, incorporated, $6 \mathrm{~kg} \mathrm{ha}^{-1}$ & 7.78 & 47.15 & 54.94 \\
\hline Soil, incorporated, $12 \mathrm{~kg} \mathrm{ha}^{-1}$ & 7.28 & 46.97 & 54.25 \\
\hline Soil, incorporated, $24 \mathrm{~kg} \mathrm{ha}^{-1}$ & 8.96 & 50.22 & 59.18 \\
\hline Foliar, $0.4 \mathrm{~kg} \mathrm{ha}^{-1}$ & 10.38 & 49.56 & 59.93 \\
\hline Seed, $40 \mathrm{~g} \mathrm{~kg}^{-1}$ & 5.68 & 51.55 & 57.23 \\
\hline \multirow[t]{2}{*}{ Control } & 8.67 & 59.74 & 68.41 \\
\hline & \multicolumn{3}{|c|}{ - F-test - } \\
\hline Control vs. others & $0.026 \mathrm{~ns}$ & $0.001 \mathrm{~ns}$ & $0.000 \mathrm{~ns}$ \\
\hline Soil vs. (foliar + seed) & $0.440 \mathrm{~ns}$ & $0.113 \mathrm{~ns}$ & $0.023 \mathrm{~ns}$ \\
\hline Foliar vs. seed & $76.208 \mathrm{~ns}$ & $1.208 \mathrm{~ns}$ & $2.487 \mathrm{~ns}$ \\
\hline Soil, incorporated vs. soil banded & $1.358^{* *}$ & $28.378^{* *}$ & $27.925^{* *}$ \\
\hline Doses in banded & $5.865^{*}$ & $9.890^{* *}$ & $15.334^{* *}$ \\
\hline Doses in incorporated & $5.382^{*}$ & $5.989^{*}$ & $10.434^{* *}$ \\
\hline CV $(\%)$ & 9.7 & 5.1 & 4.1 \\
\hline Sorghum & \multicolumn{3}{|c|}{-g glucose per $100 \mathrm{~g}$} \\
\hline Soil, banded, $2 \mathrm{~kg} \mathrm{ha}^{-1}$ & 9.13 & 58.74 & 67.87 \\
\hline Soil, banded, $4 \mathrm{~kg} \mathrm{ha}^{-1}$ & 11.56 & 66.39 & 77.95 \\
\hline Soil, banded, $8 \mathrm{~kg} \mathrm{ha}^{-1}$ & 10.77 & 41.66 & 52.43 \\
\hline Soil, incorporated, $6 \mathrm{~kg} \mathrm{ha}^{-1}$ & 11.74 & 45.42 & 57.16 \\
\hline Soil, incorporated, $12 \mathrm{~kg} \mathrm{ha}^{-1}$ & 11.23 & 45.32 & 56.55 \\
\hline Soil, incorporated, $24 \mathrm{~kg} \mathrm{ha}^{-1}$ & 11.63 & 48.29 & 59.92 \\
\hline Foliar, $0.4 \mathrm{~kg} \mathrm{ha}^{-1}$ & 11.37 & 61.70 & 73.07 \\
\hline Seed, $40 \mathrm{~g} \mathrm{~kg}^{-1}$ & 9.49 & 48.17 & 57.65 \\
\hline \multirow[t]{2}{*}{ Control } & 10.62 & 60.02 & 70.64 \\
\hline & & -F-test & \\
\hline Control vs. others & $3.630^{*}$ & $0.177 \mathrm{~ns}$ & $0.869 \mathrm{~ns}$ \\
\hline Soil vs. (foliar + seed) & $3.736^{*}$ & $19.038^{* *}$ & $10.501^{* *}$ \\
\hline Foliar vs. seed & $13.173^{* *}$ & $73.969^{* *}$ & $72.718^{* *}$ \\
\hline Soil, incorporated vs. soil banded & $12.165^{* *}$ & $103.681^{* *}$ & $61.819^{* *}$ \\
\hline Doses in banded & $3.497 \mathrm{NS}$ & $116.923^{* *}$ & $67.686^{* *}$ \\
\hline Doses in incorporated & $5.049^{*}$ & $21.293^{* *}$ & $20.432^{* *}$ \\
\hline CV $(\%)$ & 6.8 & 4.3 & 4.1 \\
\hline
\end{tabular}

According to the F-test, ${ }^{* *}$ denotes significance at $1 \%$ probability, and ns denotes not significant. 
However, when $\mathrm{Zn}$ was incorporated into the soil, a quadratic adjustment existed for the soluble carbohydrate content (Figure 2a) (minimum point of $8.7 \mathrm{~kg} \mathrm{ha}^{-1}$ ), starch content (Figure 2b) (minimum point of $\left.12.3 \mathrm{~kg} \mathrm{ha}^{-1}\right)$ and total carbohydrate content (Figure 2c) (minimum point of $11.6 \mathrm{~kg} \mathrm{ha}^{-1}$ ). This trend may have occurred due to the use of higher doses in these treatments, thereby increasing the bioavailability of $\mathrm{Zn}$ and its uptake by roots. In an experiment with cassava, Souza et al. (1991) verified that the $\mathrm{Zn}$ dosage of $4 \mathrm{~kg} \mathrm{ha}^{-1}$ in soil does not cause differences in the starch content.

With regard to the sorghum crop in the first contrast tested (control vs. other treatments (Table 2), differences occurred only for the soluble carbohydrates. Studies have demonstrated that the role of $\mathrm{Zn}$ in carbohydrate metabolism (Sharma et al., 1990) is to inhibit the transport of photoassimilates (Samarakoon and Rauser, 1979). However, little is known about the effects of $\mathrm{Zn}$ concerning the carbohydrate content in plants (Ghnaya et al., 2010).

When comparing the soil application to the plant application, the soil application resulted in a higher content of soluble carbohydrates in corn grains, and the plant application promoted higher contents of starch and total carbohydrates (Table 2).

When comparing the applications of $\mathrm{Zn}$ to plants, foliar application promoted higher contents of soluble carbohydrates, starch and total carbohydrates.

When comparing the applications of $\mathrm{Zn}$ to soil, the banded application provided higher contents of starch and total carbohydrates, but the incorporation of $\mathrm{Zn}$ into soil increased the contents of soluble carbohydrates.

Zn application demonstrated differences among doses of $\mathrm{Zn}$ applied to the soil, except for the soluble
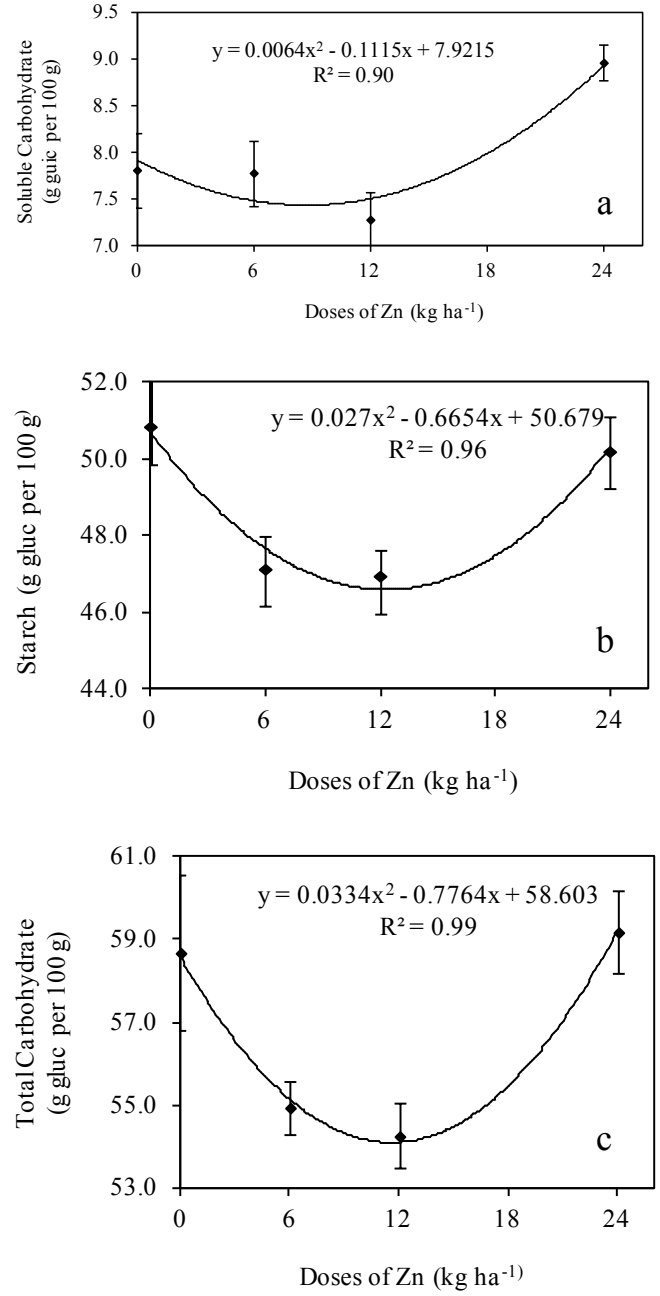

Figure 2. Contents of soluble carbohydrates (a), starch (b) and total carbohydrates (c) in corn grains according to $\mathrm{Zn}$ application in soil by incorporation.

carbohydrate content. The banded application of $\mathrm{Zn}$ promoted a quadratic adjustment in starch content (Figure 3a) (maximum point of $3.5 \mathrm{~kg} \mathrm{ha}^{-1}$ ) and total carbohydrates (Figure 3b) (maximum point of 3.4 $\left.\mathrm{kg} \mathrm{ha}^{-1}\right)$ in sorghum grains. Incorporation of $\mathrm{Zn}$ into soil promoted an increase with linear adjustment in soluble carbohydrates (Figure 4a) and a quadratic adjustment in starch content (Figure 4b) (minimum point of $\left.13.5 \mathrm{~kg} \mathrm{ha}^{-1}\right)$ and total carbohydrate content (Figure 4c) (minimum point of $13.8 \mathrm{~kg} \mathrm{ha}^{-1}$ ). 

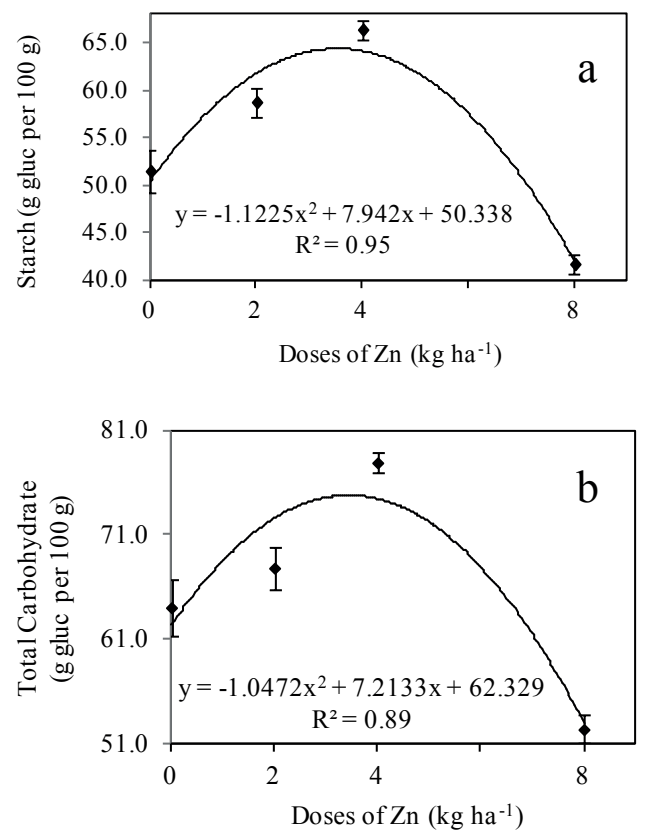

Figure 3. Contents of starch (a) and total carbohydrates (b) in sorghum grains according to the banded application of $\mathrm{Zn}$ in soil.

Effects of treatments on protein content in grains

As presented in Table 3, the first contrast (control vs. other treatments) for corn showed that the application of $\mathrm{Zn}$ promoted a higher content of protein in corn grains when compared to the control regardless of the application method. $\mathrm{Zn}$ is the micronutrient that affects protein synthesis the most in plants (Obata et al., 1999). There are over 300 enzymes that require $\mathrm{Zn}$ for structural integrity and biological function (Marschner, 1995). According to Sharma et al. (1982), the protein synthesis rate and content in plants with Zn deficiency are drastically reduced. Such decrement is attributed to decreased RNA as well as the deformation and reduction of ribosomes (Brown et al., 1993).

No differences were observed when $\mathrm{Zn}$ applications in soil and plants were compared. Nevertheless, comparison of the $\mathrm{Zn}$ treatment via leaves with the treatment via seeds indicated that foliar application provided a higher content of protein in grains.
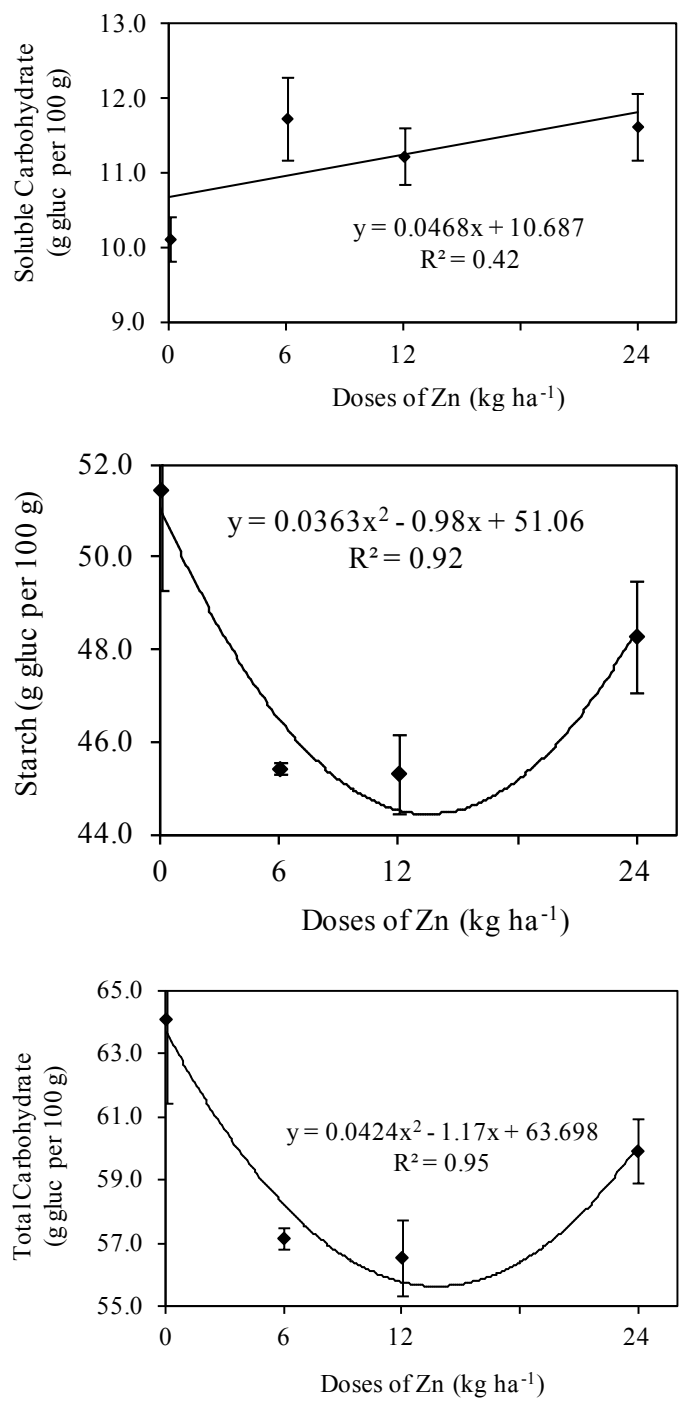

Figure 4. Contents of soluble carbohydrates (a), starch (b) and total carbohydrates (c) in sorghum grains according to $\mathrm{Zn}$ application in soil by incorporation.

Comparison of the application of this micronutrient in soil demonstrated that the banded application of Zn promoted greater increases in protein content than the incorporated treatment.

$\mathrm{Zn}$ application resulted in differences among doses when incorporated in soil. Zn applied in such manner promoted increases with linear adjustment for the protein content of corn grains $\left(y=0.029 x+7.726 ; R^{2}=0.72\right)$. When studying the effect of $\mathrm{Zn}$ in a nutrient solution on beans, Cakmak et al. (1989) Zn observed that the Zn 
Table 3. Summary of the variance analysis regarding the protein content in corn and sorghum grains according to different $\mathrm{Zn}$ application methods.

\begin{tabular}{|c|c|c|}
\hline Zinc application & Corn & Sorghum \\
\hline & \multicolumn{2}{|c|}{$\mathrm{g} \mathrm{kg}^{-1}$} \\
\hline Soil, banded, $2 \mathrm{~kg} \mathrm{ha}^{-1}$ & 8.69 & 9.81 \\
\hline Soil, banded, $4 \mathrm{~kg} \mathrm{ha}^{-1}$ & 8.45 & 10.03 \\
\hline Soil, banded, $8 \mathrm{~kg} \mathrm{ha}^{-1}$ & 8.69 & 9.72 \\
\hline Soil, incorporated, $6 \mathrm{~kg} \mathrm{ha}^{-1}$ & 7.71 & 9.04 \\
\hline Soil, incorporated, $12 \mathrm{~kg} \mathrm{ha}^{-1}$ & 7.95 & 9.44 \\
\hline Soil, incorporated, $24 \mathrm{~kg} \mathrm{ha}^{-1}$ & 8.53 & 10.07 \\
\hline Foliar, $0.4 \mathrm{~kg} \mathrm{ha}^{-1}$ & 8.37 & 9.95 \\
\hline Seed, $40 \mathrm{~g} \mathrm{~kg}^{-1}$ & 7.92 & 9.20 \\
\hline \multirow[t]{2}{*}{ Control } & 7.93 & 9.61 \\
\hline & \multicolumn{2}{|c|}{-F-test } \\
\hline Control vs. others & $6.258^{* *}$ & $0.077 \mathrm{~ns}$ \\
\hline Soil vs. (foliar + seed) & $3.020 \mathrm{~ns}$ & $0.850 \mathrm{~ns}$ \\
\hline Foliar vs. seed & $5.786^{*}$ & $12.783^{* *}$ \\
\hline Soil, incorporated vs. soil banded & $24.405^{* *}$ & $7.804^{* *}$ \\
\hline Doses in banded & $0.943 \mathrm{~ns}$ & $6.640^{*}$ \\
\hline Doses in Incorporated & $5.735^{*}$ & $13.090^{* *}$ \\
\hline CV $(\%)$ & 3.3 & 3.1 \\
\hline
\end{tabular}

According to the F-test, ${ }^{* *}$ and * denote significance at 1 and $5 \%$ probability, and ns denotes not significant.

supply increases the protein content of leaves from this culture as compared to plants that did not receive $\mathrm{Zn}$. Such increment in protein content can be attributed to $\mathrm{Zn}$ application increasing plant $\mathrm{Zn}$ uptake (Table 3), which is reflected by protein synthesis because Zn catalyzes RNA polymerase, inhibits RNAse and is a part of the ribosome structure (Prado, 2008).

The first contrast (control vs. other treatments) for sorghum showed that there were no differences in the protein content of sorghum grains in all tested treatments (Table 3), and no differences were found when comparing the addition of $\mathrm{Zn}$ to soil with the addition to plants. However, $\mathrm{Zn}$ deficiency disrupts protein synthesis (RNA) and nitrate reduction, thereby promoting a decrease in RNA levels, which results in less protein synthesis and difficulties in cell division. These effects can be explained by the fact that $\mathrm{Zn}$ inhibits RNAse
(RNA disintegrator) and is a part of the RNA polymerase, which synthesizes RNA (Malavolta, 2006).

Compared to seed application of Zn, Znfoliar application of $\mathrm{Zn}$ promoted higher protein content in grains. Mousavi et al. (2007) studied foliar application of $\mathrm{Zn}$ sulfate in potato crops and showed that higher doses of this element promotes increased protein content in this culture.

Compared to incorporation of $\mathrm{Zn}$, banded application of $\mathrm{Zn}$ caused greater increases of protein content.

$\mathrm{Zn}$ application via soil resulted in different protein contents in grains. The banded application of $\mathrm{Zn}$ caused an increase with quadratic adjustment of the protein content in grains $\left(y=-0.0205 \mathrm{x}^{2}+\right.$ $\left.0.1815 \mathrm{x}+9.5879 ; \mathrm{R}^{2}=0.94\right)$, and the $4.4 \mathrm{~kg} \mathrm{ha}^{-1}$ 
dose provided the highest content. Moreover, incorporated application of $\mathrm{Zn}$ resulted in a quadratic adjustment $\left(\mathrm{y}=0.0038 \mathrm{x}^{2}-0.0662 \mathrm{x}+\right.$ $9.526 ; \mathrm{R}^{2}=0.84$ ) (minimum point of $8.7 \mathrm{~kg} \mathrm{ha}^{-1}$ ).
In $\mathrm{Zn}$ deficiency conditions, several metabolic processes in plants, such as RNA metabolism and protein synthesis, are compromised (Kitagishi; Obata, 1986).

\title{
Resumen
}

\begin{abstract}
A.P. Puga, R.M. Prado, B. Mattiuz, D.W. Vale y I.M. Fonseca. 2013. Efecto de diferentes métodos de aplicación y dosis de zinc sobre la composición química de los granos de maíz y sorgo, cultivados en un suelo Oxisol. Cien. Inv. Agr. 40(1):97-108. Los suelos tropicales, en general, tienen una baja concentración de zinc $(\mathrm{Zn})$, y la deficiencia de este micronutriente es reconocida como un problema nutricional mundial para la producción de cereales y para los seres humanos. Así, el objetivo de este estudio fue evaluar los efectos de diferentes métodos de aplicación de Zn sobre la calidad del grano de maíz y sorgo. Para esto, se realizaron dos experimentos en el área experimental de FCAV/UNESP, Jaboticabal, Brasil. Se aplicaron nueve tratamientos: tres dosis de $\mathrm{Zn}$ aplicadas en forma localizada en los surcos de las semillas, tres dosis de $\mathrm{Zn}$ aplicadas en forma incorporada al suelo $(0-20 \mathrm{~cm}$ de profundidad), una dosis aplicada en forma foliar, y el tratamiento control (sin aplicación de $\mathrm{Zn}$ ); dispuestos en un diseño de bloques completos al azar con cuatro repeticiones. Las variables medidas fueron: contenido de $\mathrm{Zn}$, proteínas y carbohidratos en los granos de maíz y sorgo. La adición de Zn, independientemente del modo, promovió mayores niveles de este micronutriente en los granos de maíz y sorgo. El modo de aplicación de Zn en el suelo de una forma localizada mostró mayores niveles de carbohidratos, almidón y proteína en las semillas de ambos cultivos. La aplicación de $\mathrm{Zn}$ en el suelo de modo incorporado resultó en altos niveles de carbohidratos solubles en los granos de maíz y sorgo.
\end{abstract}

Palabras clave: Hidratos de carbono, proteínas, Sorghum bicolor, Zea mays, Zn.

\section{References}

Alloway, B.J. 2009. Soil factors associated with zinc deficiency in crops and humans. Environmental Geochemistry and Health 31:537-548.

Bataglia, O.C., A.M.C. Furlani, J.P.F. Teixeira, P.R. Furlani, and J.R. Gallo. 1983. Métodos de análise química de plantas. Boletim Técnico 78. Instituto Agronômico. Campinas. 48 pp.

Brown, P.H., I. Cakmak, and Q. Zhang. 1993. Form and function of zinc in plants. In: Zinc in Soils and Plants. Robson, A.D. (ed.). The Netherlands: Kluwer Academic Publishers - Dordrecht.
Cakmak, I., H. Marschner, and F. Bangerth. 1989. Effect of zinc nutritional status on growth, protein metabolism and levels of indole-3-acetic acid and other phytohormones in bean (Phaseolus vulgaris L.). Journal of Experimental Botany 40: 405-412.

Cakmak, I., M. Kalayci, H. Ekiz, H.J. Braun, and A. Yilmaz. 1999. Zinc deficiency as an actual problem in plant and human nutrition in Turkey: A NATO-Science for Stability Project, Field Crops Research 60:175-188.

Cakmak, I., R. Graham, and R.M. Welch. 2002. Agricultural and molecular genetic approaches to improving nutrition and preventing micronutrient 
malnutrition globally. In: Cakmak, I., and R.M. Welch (eds.). Encyclopedia of Life Support Systems. Eolss, Oxford. p. 1075-1099.

Cakmak, I. 2008. Enrichment of cereal grains with zinc: Agronomic or genetic biofortification? Plant Soil 308: 1-17.

Cakmak, I., M. Kalayci, Y. Kaya, Y. Torun, A.A. Aydin, N. Wang, Y. Arisoy, Z. Erdem, H. Yazici, A. Gokmen, O. Ozturk, and W.J. Horst. 2010. Biofortification and localization of zinc in wheat grain. Journal of Agricultural and Food Chemistry 58: 9092-9102.

Dechen, A.R, and G.R. Nachtigall. Micronutrientes. 2006. In: Fernandes, M. S. (ed.) Nutrição Mineral de Plantas. Viçosa: Sociedade Brasileira de Ciência do Solo. p. 327-354.

Embrapa. 2006. Centro Nacional e Pesquisa em Solos. Sistema Brasileiro de Classificação de Solos. Brasilia: Embrapa-SPI, Rio de Janeiro: EmbrapaSolos. 306 pp.

Ferreira, A.C.B., G.A.A. Araújo, P.R.G. Pereira, and A.A. Cardoso. 2001. Características agronômicas e nutricionais do milho adubado com nitrogênio, molibdênio e zinco. Scientia Agricola 58:131-138.

Galrão, E.Z. 1994. Métodos de correção da deficiência de zinco para o cultivo do milho num Latossolo Vermelho-Escuro argiloso sob cerrado. Revista Brasileira de Ciência do Solo 18:229-233.

Gibson, R.S. 2006. Zinc: the missing link in combating micronutrient malnutrition in developing countries. Proceedings of the Nutrition Society 65:51-60.

Ghnaya, A.B., A. Hourmant, S. Cerantola, N. Kervarec, J.Y. Cabon, M. Branchard, and G. Charles. 2010. Influence of zinc on soluble carbohydrate and free amino acid levels in rapeseed plants regenerated in vitro in the presence of zinc. Plant Cell, Tissue and Organ Culture 102:191-197.

Graham, R.D., J.S. Ascher, and S.C. Hynes. 1992. Selecting zinc-efficient varieties for soils of low zinc status. Plant Soil 146:241-250.

Hotz, C., and K.H. Brown. 2004. Assessment of the risk of zinc deficiency in populations and options for its control. Food and Nutrition Bulletin 25:S91-S204.
Hemantaranjan, A., and O.K. Garg. 1988. Iron and zinc fertilization with reference to the grain quality of Triticum aestivum L. Journal of Plant Nutrition 11:1439-1450.

Kanwal, S., A.M.R. Rahmatullah, and R. Rashid. 2010. Zinc partitioning in maize grain after soil fertilization with zinc sulfate. International Journal of Agriculture \& Biology 12:299-302.

Kitagishi, K., and H. Obata. 1986. Effects of zinc deficiency on the nitrogen metabolism of meristematic tissues of rice plants with reference to protein synthesis. Soil Science and Plant Nutrition 32:397-405.

Malavolta, E. 2006. Manual de nutrição mineral de plantas. São Paulo: Ceres. 638 pp.

Marschner, H. 1995. Mineral nutrition of higher plants. 2nd ed. London: Academic Press. 889 pp.

Maret, W., and H.H. Sandstead. 2006. Zinc requirements and the risks and benefits of zinc supplementation. Journal of Trace Elements in Medicine and Biology 20:3-18.

Moinuddin, P.I. 2010. Effect of zinc nutrition on growth, yield, and quality of forage sorghum in respect with increasing potassium application rates. Journal of Plant Nutrition 33:2062-2081.

Mousavi, S.R., M. Galavi, and G. Ahmadvand. 2007. Effect of zinc and manganese foliar application on yield, quality and enrichment on potato (Solanum tuberosum L.). Asian Journal of Plant Sciences: 8:1256-1260.

Nelson, W.L., and A. Mehlich. 1953. The Development, evaluation, and use of soil tests for phosphorus availability. Agronomy 4:153-188.

Newell, M.M. 2008. Nutritionally improved agricultural crops. Plant Physiology 147:939-953.

Obata, H., S. Kawamura, K. Senoo, and A. Tanaka. 1999. Changes in the level of protein and activity of $\mathrm{Cu} / \mathrm{Zn}$-superoxide dismutase in zinc deficient rice plant, Oryza sativa L. Soil Science and Plant Nutrition 45:891-896.

Ozturka, L., M.A. Yazicia, C. Yucelb, A. Torunb, C. Cekicc, A. Bagcid, H. Ozkanb, H. Braune, Z. Sayersa, and I. Icakmaka. 2006. Concentration and localization of zinc during seed development and germination in wheat. Physiologia Plantarum: 128:144-152. 
Peck, A.W., G.K. Mcdonald, and R.D. Graham. 2008. Zinc nutrition influences the protein composition of flour in bread wheat (Triticum aestivum L.). Journal of Cereal Science 47:266-274.

Peleg, Z., Y. Saranga, A. Yazici, T. Fahima, L. Ozturk, and I. Cakmak. 2008. Grain zinc, iron and protein concentrations and zinc-efficiency in wild emmer wheat under contrasting irrigation regimes. Plant and Soil 306:57-67.

Prado, R.M., L.M. Romualdo, D.E. Rozane, A.A. Vidal, and A.V. Marcelo. 2008. Modos de aplicação de zinco na nutrição e na produção de matéria seca do milho BRS 1001. Bioscience Journal 24:67-74.

Prasad, A.S. 2007. Zinc: Mechanisms of host defense. Journal of Nutrition 137:1345-1349.

Puga, A.P. 2011. Modos de aplicação de zinco em milho e sorgo cultivados em Latossolo Vermelho distrófico. Jaboticabal. 101 pp.

Raij, B. van, J.A. Quaggio, H. Cantarella and C.A. Abreu. 1997. Interpretação de resultados de análises de solo. In: Raij, B. van., H. Cantarella, J.A. Quaggio, and A.M.C. Furlani (eds.). Recomendações de adubação e calagem para o estado de São Paulo. 2 ed. rev. Campinas: Instituto Agronômico. p. 8-13.

Raij, B. van., J.C. Andrade, H. Cantarella, and J.A. Quaggio (eds.). 2001. Análise química para avaliação da fertilidade do solo: Instituto Agronômico. Campinas. 285 pp.

Samarakoon, A.B., and W. Rauser. 1979. Carbohydrate level and photoassimilate export from leaves of Phaseolus vulgaris exposed to excess cobalt, nickel and zinc. Plant Physiology 63:1165-1169.
Sharma, C.P., P.N. Sharma, S.S. Bisht, and B.D. Nautiyal. 1982. Zinc deficiency induced changes in cabbage. In: Proceedings of the Ninth Plant Nutrition Colloquium,Warwick, England, A. Scaife (eds.). Commonwealth Agricultural Bureau, Farnham Royal Bucks.

Sharma, P.N., C. Chatterjee, S.C. Agarwala, and C.P. Sharma. 1990. Zinc deficiency and pollen fertility in maize (Zea mays). Plant Soil 124:221-225.

Somogyi, M. 1952. Notes on sugar determination. Journal of Biological Chemistry 195:19-23.

Souza, L.D., J.D. Gomes, and R.C. Caldas. 1991. Interação calagem, fósforo e zinco para a cultura da mandioca em Sinop (MT). Embrapa. 21 pp.

Welch, R.M. 1986. Effects of nutrient deficiencies on seed production and quality. Advances in Plant Nutrition 2:205-247.

Welch, R.M. 2002. The impact of mineral nutrients in food crops on global human health. Plant Soil 247: 83-90.

WHO. 2002. Reducing Risks, Promoting Healthy Life. Methods Summaries for Risk Factors assessed in Chapter 4. WHO (World Health Organization). Geneva, Switzerland. 33 pp.

Wiles, P.G., I.K. Gray, and R.C. Kissling. 1998. Routine analysis of protein by Kjeldahl and Dumas methods: review and interlaboratory study using dairy products. Journal of AOAC International 81: 620-632.

Yilmaz, A., H. Ekiz, B. Torun, I. Gultekin, S. Karanlik, S.A. Bagci, and I. Camak. 1997. Effect of different zinc application methods on grain yield and zinc concentration in wheat grown on zinc-deficient calcareous soils in Central Anatolia. Journal of Plant Nutrition 20:461-471. 